\title{
Morphological and Molecular Characterization of the Eggs of Some Noctuid Species Associated with Soybean in Brazil
}

Author(s): Adrian Augusto Sosa Gomez Rolim , Silvia Akimi Cavaguchi Yano, Alexandre Specht, Celia Guadalupe Tardelli De Jesus Andrade, and Daniel Ricardo Sosa-Gómez

Source: Annals of the Entomological Society of America, 106(5):643-651. 2013.

Published By: Entomological Society of America

URL: http://www.bioone.org/doi/full/10.1603/AN13049

BioOne (www.bioone.org) is a nonprofit, online aggregation of core research in the biological, ecological, and environmental sciences. BioOne provides a sustainable online platform for over 170 journals and books published by nonprofit societies, associations, museums, institutions, and presses.

Your use of this PDF, the BioOne Web site, and all posted and associated content indicates your acceptance of BioOne's Terms of Use, available at www.bioone.org/page/terms of use.

Usage of BioOne content is strictly limited to personal, educational, and non-commercial use. Commercial inquiries or rights and permissions requests should be directed to the individual publisher as copyright holder. 


\title{
Morphological and Molecular Characterization of the Eggs of Some Noctuid Species Associated With Soybean in Brazil
}

\author{
ADRIAN AUGUSTO SOSA GOMEZ ROLIM, ${ }^{1}$ SILVIA AKIMI CAVAGUCHI YANO ${ }^{2}$ \\ ALEXANDRE SPECHT, ${ }^{3}$ CELIA GUADALUPE TARDELLI DE JESUS ANDRADE, ${ }^{4}$ \\ AND DANIEL RICARDO SOSA-GÓMEZ2,5
}

\begin{abstract}
Ann. Entomol. Soc. Am. 106(5): 643-651 (2013); DOI: http://dx.doi.org/10.1603/AN13049
ABSTRACT The most important species of Lepidoptera that attack soybean, in descending order of importance, are Chrysodeixis includens (Walker), Anticarsia gemmatalis Hübner, Spodoptera cosmioides (Walker), Spodoptera eridania (Stoll), and Spodoptera albula (Walker). In addition, Rachiplusia nu (Guenée) is one of the most common Plusiinae in the southern region of Brazil, encompassing the states of Paraná, Santa Catarina, and Rio Grande do Sul. The correct identification of these species is essential for choosing the appropriate control measures, as they differ in their susceptibility to insecticides and biological control agents. To distinguish Lepidoptera species commonly found in Brazil, the eggshells of all these species were morphologically characterized by scanning electron microscopy. Diagnostic characters for differentiating species include shape of rosette petals, number of primary cells, number of secondary cells, number of ribs, and rosette diameter. Also, a molecular diagnostic method using polymerase chain reaction and restriction fragment length polymorphism (PCR-RFLP) analysis was developed to distinguish noctuid species commonly found in Brazil. A 658-bp region of the mitochondrial DNA cytochrome oxidase subunit I gene was amplified using PCR and then sequenced. The five Lepidoptera species were distinguished by restriction enzymes Bpm I and MboI. RFLPs produced by Bpm I endonuclease were useful to discriminate species from within Spodoptera (S. cosmioides, S. eridania, and S. albula) and R. nu from C. includens. However, Bpm I did not digest the amplicons from S. eridania and C. includens, which were discriminated by RFLP patterns produced by the restriction enzyme MboI. PCRRFLP can be performed in a short period, and it is useful to distinguish the most important Brazilian Lepidoptera soybean pests.
\end{abstract}

KEY WORDS Chrysodeixis includens, Rachiplusia nu, Spodoptera cosmioides, Spodoptera eridania, Spodoptera albula

The most important species of Lepidoptera that attack soybean, in descending order of importance, are Chrysodeixis includens (Walker), Anticarsia gemmatalis Hübner, Spodoptera cosmioides (Walker), Spodoptera eridania (Stoll), and Spodoptera albula (Walker). In addition, Rachiplusia nu (Guenée) is one of the most common Plusiinae in the southern region of Brazil, encompassing the states of Paraná, Santa Catarina, and Rio Grande do Sul (Sosa-Gómez et al. 2010). The correct identification of these species is essential for choosing the appropriate control measures, as they

\footnotetext{
${ }^{1}$ Departamento de Entomologia e Acarologia, Escola Superior de Agricultura "Luiz de Queiroz", Universidade de São Paulo (ESALQUSP), Avenida Pádua Dias, 11, 13418-900, Piracicaba, SP, Brazil. ${ }^{2}$ Embrapa Soja, C. P. 231, 86001-970, Londrina, PR, Brazil.

${ }^{3}$ Embrapa Cerrados, C.P. 08223, 73310-970, Brasília, DF, Brazil.

${ }^{4}$ Laboratório de Microscopia e Microanálise, Universidade Estadual de Londrina, Rodovia Celso Garcia Cid, PR 445, km 380, Campus Universitário, 86055-900, Londrina, PR, Brazil.

${ }^{5}$ Corresponding author, e-mail: daniel.sosa-gomez@embrapa.br.
}

differ in their susceptibility to insecticides and biological control agents (Braga et al. 2011).

The identification of these species may be difficult under certain circumstances, such as at the egg stage, as small larvae, or when adult wings have no scales, especially when they are very close morphologically, such as in the cases of S. albula and S. eridania or C. includens and R. nu. However, adult specimens can be recognized, with some expertise, through the dissection of their genitalia, following the method described by Pogue (2002) and Eichlin and Cunningham (1978).

To the best of our knowledge, the eggs of just a few Lepidotera species associated with soybean have already been described in detail. The first studies briefly described the eggs of A. gemmatalis, Agrotis ipsilon (Hufnagel), Heliothis virescens (F.), S. albula [mentioned as Prodenia sunia (Guenée)], Spodoptera frugiperda (J. E. Smith), and C. includens, and their descriptions did not allow differentiation among species (Peterson 1961, 1964). Cônsoli et al. (1999) described and illustrated the microstructure of the eggs of $A$. 
gemmatalis, H. virescens, and S. frugiperda. Furthermore, the morphological characterization of the eggs of S. eridania was performed by Valverde (2007). However, when morphological identification is impossible, molecular diagnostic protocols have been recommended to distinguish among species (Lewter and Szalanski 2007). Currently, DNA extraction can be performed within a few minutes, followed by amplification and restriction analysis to obtain diagnostic DNA profiles in one or two working days. The purpose of this study was to distinguish the eggs of the most important soybean Lepidoptera pests in Brazil, using both morphological and molecular techniques. Identification of eggs among species will distinguish them so that chemical and biological control strategies can be implemented.

\section{Materials and Methods}

Insects. Specimens of C. includens were collected in Rondonópolis, MT ( $\left.16^{\circ} 28^{\prime} 15^{\prime \prime} \mathrm{S}, 54^{\circ} 38^{\prime} 15^{\prime \prime} \mathrm{W}\right)$, during the 2008 and 2009 soybean growing season; $R$. $n u$ was collected in Vacaria, RS ( $28^{\circ} 30^{\prime} 44^{\prime \prime} \mathrm{S}, 50^{\circ} 56^{\prime} 02^{\prime \prime} \mathrm{W}$ ), and in Monte Redondo, Tucumán, Argentina (27 $48^{\prime} 2^{\prime \prime} \mathrm{S}, 65^{\circ} 26^{\prime} 08^{\prime \prime} \mathrm{W}$ ), from soybean plants; and $S$. albula was collected in Jaboticabal, SP $\left(21^{\circ} 15^{\prime} 22^{\prime \prime} \mathrm{S}\right.$, $\left.48^{\circ} 18^{\prime} 58^{\prime \prime} \mathrm{W}\right)$. S. eridania and S. cosmioides adult specimens and eggs were obtained from larvae reared in the laboratory of Embrapa Soja in Londrina, PR, Brazil. Field populations of $S$. cosmioides were collected in Pelotas, RS ( $31^{\circ} 0^{\prime} 7^{\prime \prime} \mathrm{S}, 52^{\circ} 26^{\prime} 09^{\prime \prime} \mathrm{W}$ ), from soybean and Ricinus communis L. plants; S. eridania was collected in Santa Helena de Goiás, GO (17 $50^{\prime} 11.5^{\prime \prime} \mathrm{S}, 49^{\circ}$ $\left.39^{\prime} 12^{\prime \prime} \mathrm{W}\right)$, from cotton plants; and A. gemmatalis in Sertanópolis, PR ( $\left.23^{\circ} 03^{\prime} 44^{\prime \prime} \mathrm{S}, 51^{\circ} 00^{\prime} 50^{\prime \prime} \mathrm{W}\right)$, from soybean plants. The identification of the species was confirmed in adult specimens based on their genitalia morphology according to Eichlin and Cunningham (1978), Pogue (2002), and Barbut (2008).

Morphological Study. Adults were fed a $10 \%$ honey solution. Eggs from each species $(n=30)$ were dipped in KAAD solution $(7.1 \%$ kerosene, $14.3 \%$ glacial acetic acid, $71.5 \%$ ethanol, and $7.1 \%$ dioxane) and kept at $-20^{\circ} \mathrm{C}$ for $24 \mathrm{~h}$. After this, the eggs were transferred to $70 \%$ ethanol; the silk at the top of the eggs was removed, and they were cut above the equatorial line with a surgical scalpel. The top of the eggs was embedded in Entellan (Merck KGaA, Darmstadt, Germany) and mounted on microscope slides. The characteristics of the eggs were observed under a phase contrast microscope $(400 \times)$ (Olympus BX50 F-3, Tokyo, Japan). The eggs were photographed using a digital camera Moticam 2300 3.0M (Motic China Group Co. Ltd., Xiamen, China) to observe possible specific morphological differences, and the measures of the eggs were performed using the Motic Image version 2.0 software (Motic China Group Co. Ltd.). The morphology of the eggshells as well as the silk covering them were characterized using a scanning electron microscope (SEM) (FEI Quanta 200 FEG FEI Co., Eindhoven, The Netherlands) and gold coating. Features such as egg shape, diameter, height,
Table 1. Measurements (micrometers) of surface structures of the eggshell of two Plusiinae species; mean (range) of 30 observations

\begin{tabular}{lcc}
\hline \hline Surface structure & C. includens & R. nu \\
\hline Egg ht & $301(274-340)$ & $324(300-350)$ \\
Egg diam & $530.1(490-544)$ & $560.0(544-620)$ \\
No. primary cells & $8.4(6-10)$ & $7.7(6-9)$ \\
No. secondary cells & $12.2(8-15)$ & $12.1(11-13)$ \\
No. micropyles & $3.9(3-6)$ & $3.7(3-4)$ \\
No. ribs & $33.8(32-37)$ & $36.2(33-41)$ \\
Rosette diam & $36.7(30.4-41.9)$ & $43.2(34.8-51.0)$ \\
\hline
\end{tabular}

micropylar area, number of micropyles, number of primary cells, and number of ribs were observed. Measurements are given in $\mu \mathrm{m}$ as means and standard error of the mean. Voucher specimens were deposited at the Coleção de Insetos, Embrapa Soja.

Molecular Study. Two methods were used for DNA extraction-the CTAB protocol for moth legs (Rogers and Bendich 1988) and the Chelex 100 method for individual eggs (Hoy 1994).

Samples of all the legs of 10-29 adult individuals from each species were submitted to sequencing analysis, and polymerase chain reaction and restriction fragment length polymorphism (PCR-RFLP) was performed in at least 10 adult and 5 egg samples. DNA was amplified successfully, including the DNA extracted from single eggs, using the Chelex 100 protocol (Hoy 1994). PCR was performed using primers LCO 1490-J-1514 (5'-GGTCAACAAATCATAAAGATATT GG-3') and HCO 2198-N-2175 (5'-TAAACTTCAG GGTGACCAAAAAATCA-3') (Integrated DNA Technology, Inc., Coralville, IA), designed by Folmer et al. (1994) and described by Simon et al. (1994). The expected size of the product was $680 \mathrm{bp}$, corresponding to the initial portion of the cytochrome oxidase subunit 1 (COI) gene. The PCR reaction had a total volume of $25 \mu \mathrm{l}$, containing $10 \mathrm{ng}$ of noctuid DNA and $10 \mu \mathrm{M}$ of each primer. The PCR reaction was performed using a PTC 200 thermal cycler (MJ Research Inc., Watertown, MA), programmed for 34 cycles of $94^{\circ} \mathrm{C}$ for $1 \mathrm{~min}, 48^{\circ} \mathrm{C}$ for $1 \mathrm{~min}$, and $72^{\circ} \mathrm{C}$ for $1.5 \mathrm{~min}$, with a final extension at $72^{\circ} \mathrm{C}$ for $5 \mathrm{~min}$. PCR amplicons were separated by electrophoresis on a $1.5 \%$ agarose gel run at $120 \mathrm{~V}$ for $2.5 \mathrm{~h}$ in TBE buffer. Photos are images of ethidium bromide-treated gels. PCR amplification products were cloned directly into the TOPO vector system (Invitrogen, Carlsbad, CA) using the manufacturer's protocol. Both strands of positive clones were sequenced using BigDye Terminator v3.1 Cycle Sequencing Kit (Applied Biosystems, Foster City, CA) on an ABI PRISM 3100 Genetic Analyzer (Applied Biosystems). Chromatograms were visualized and edited using Sequencher 4.1.4 software (Gene Codes Corporation, Ann Arbor, MI; http:// www.genecodes.com) to measure the reliability of the data, and good quality sequences were used to build a consensus sequence for each sample. Consensus sequences of the COI partial gene were multiple aligned using ClustalW (Thompson et al. 1994) with default parameters. The biological sequence alignment editor Bioedit (Ibis Biosciences, Carlsbad, 


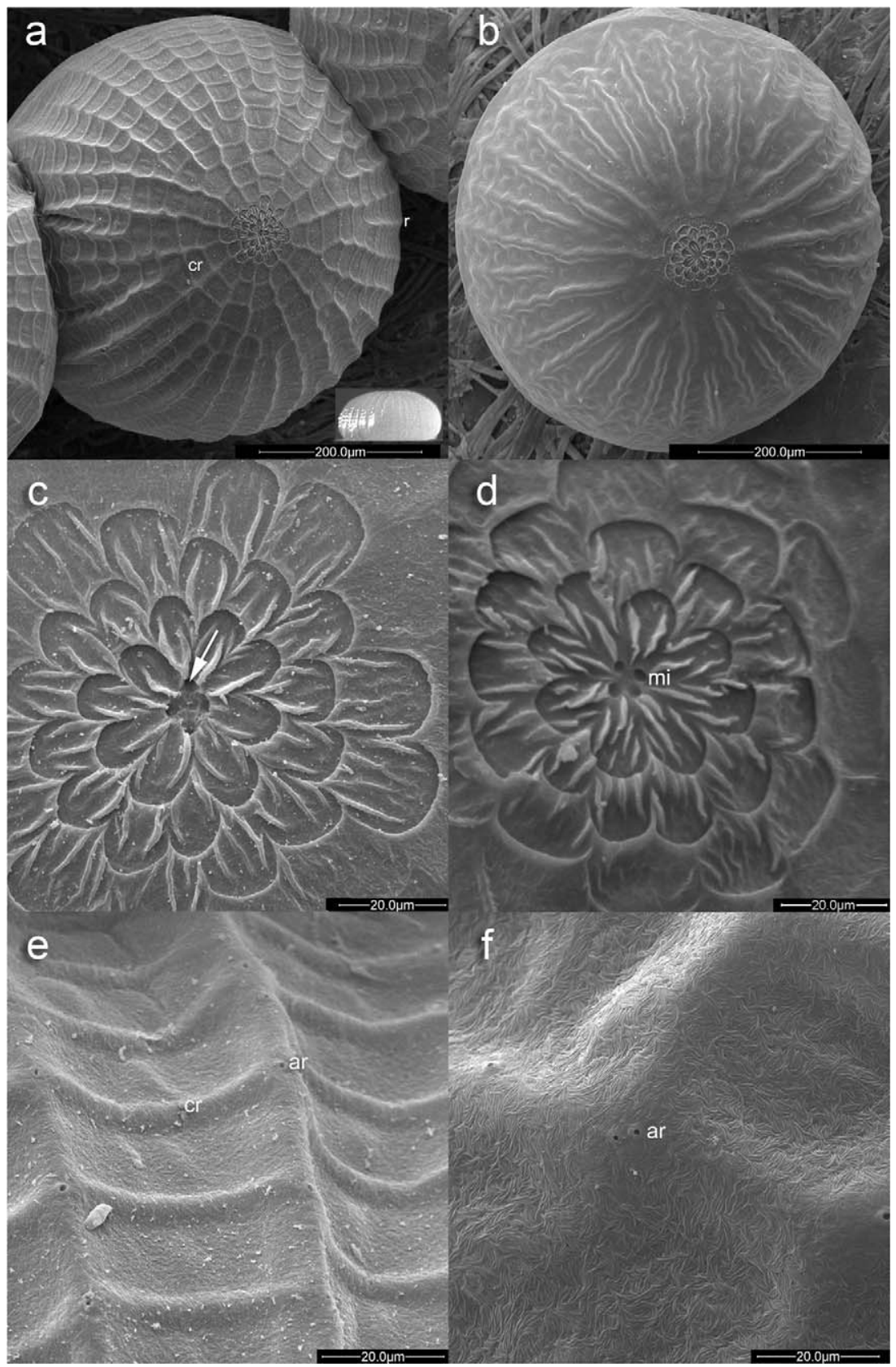

Fig. 1. (a) Eggshell surface topography of C. includens (inset, lateral view). (b) Eggshell surface topography of R. nu. (c) Micropylar rosette of $C$. includens (arrow, micropyle). (d) Micropylar rosette of $R$. nu. (e) Surface fine texture of $C$. includens. (f) Surface fine texture of R. nu. r, ribs; cr, crossribs; mi, micropyle; ar, aeropyle.

CA; http:/ / www.mbio.ncsu.edu/bioedit/bioedit. html) was used to identify restriction sites. PCR amplification products of DNA from eggs and legs were digested at $30^{\circ} \mathrm{C}$ for $2 \mathrm{~h}$ with restriction enzyme Bpm I (Fermentas International Inc., Glen Burnie, MD) and at $37^{\circ} \mathrm{C}$ for $3 \mathrm{~h}$ with restriction enzyme MboI (Invitrogen, Life Technologies Corporation, Grand Island, NY), following the manufacturers' recommendations. Fragments were visualized using elec- trophoresis on a $2 \%$ agarose gel stained with ethidium bromide and a 100-base pair (bp) DNA ladder (GeneRuler, Fermentas International Inc., Glen Burnie, MD). The agarose gels were photographed using a transilluminator (L-PIX, Loccus Biotecnologia, Cotia, SP, Brazil). Nucleotide sequences were submitted to the National Center for Biotechnology Information (NCBI; GenBank KC354733.1KC354738.1 and KF261121-KF261200). 


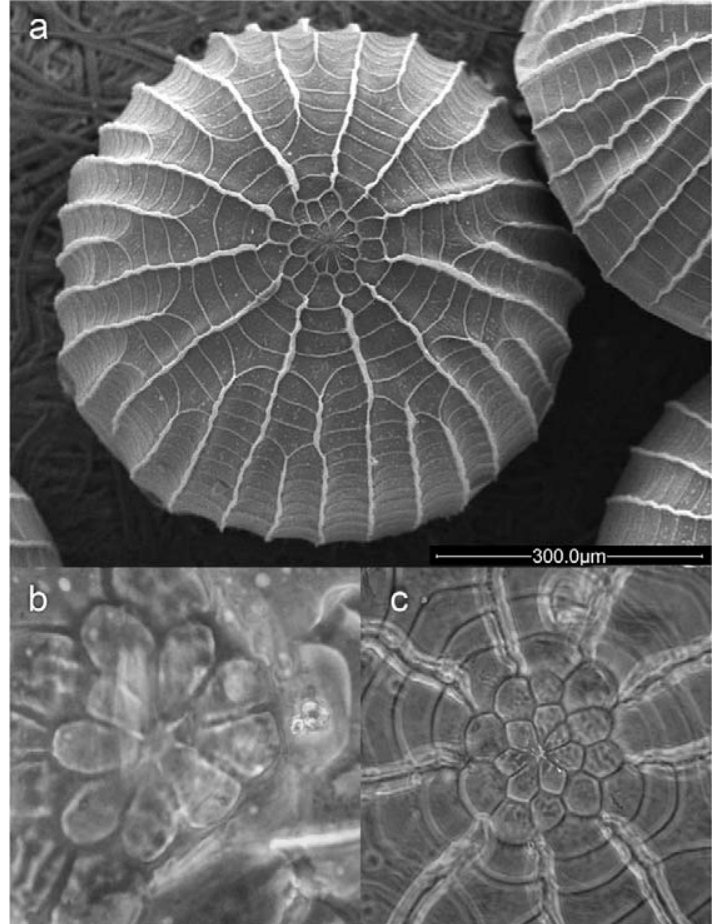

Fig. 2. (a) Eggshell surface topography of A. gemmatalis. (b) and (c) Micropylar rosette of A. gemmatalis.

\section{Results}

C. includens and R. $n u$ frequently lay a single egg on a plant, but they can also lay them in small groups of two to six. In both species, the color of the eggs ranges from pale yellow to cream. $R$. $n u$ lays slightly larger eggs than $C$. includens in diameter as well as in height, and the primary cells forming the micropylar rosette in the former are fused (Olivares et al. 2005). Furthermore, the eggs of $R$. nu generally have bigger rosette diameters and numbers of radial ribs (Table 1). In both species, the micropylar region can be depressed, and its deep part is the outer border of the petals that constitute the rosette.

The eggs of $C$. includens are hemispherical in shape, with a slightly flattened top and a flattened base (Fig. la, inset). The micropylar rosette is composed of 6-10 petals (Fig. 1c), surrounded by two concentric rosettes, with gradually bigger petals on the outside border (Fig. 1c); the outer border of the petals in the third rosette is not always obvious. The flanks of the eggs have conspicuous ribs and cross-ribs (Fig. 1a and e). Aeropyles are present on the conjunction points of the ribs and cross-ribs, and not rarely, they can be found in pairs (Fig. 1e).

The eggs of $R$. nu sometimes have flattened hemispheres at both poles (Fig. 1b). The micropylar rosette is similar to C. includens, but the lateral ribs of the eggs are not as conspicuous as in C. includens, and their edges are usually smooth (Fig. 1b). Aeropyles are present on the conjunction points of the inconspicuous ribs and cross-ribs (Fig. 1f).

The eggs of A. gemmatalis have very conspicuous ribs (Fig. 2a) that are evident under optical microscopy (Fig. 2c). Cônsoli et al. (1999) described these ribs as $9-10$ well-defined ridges that reach the cells surrounding the micropyle.

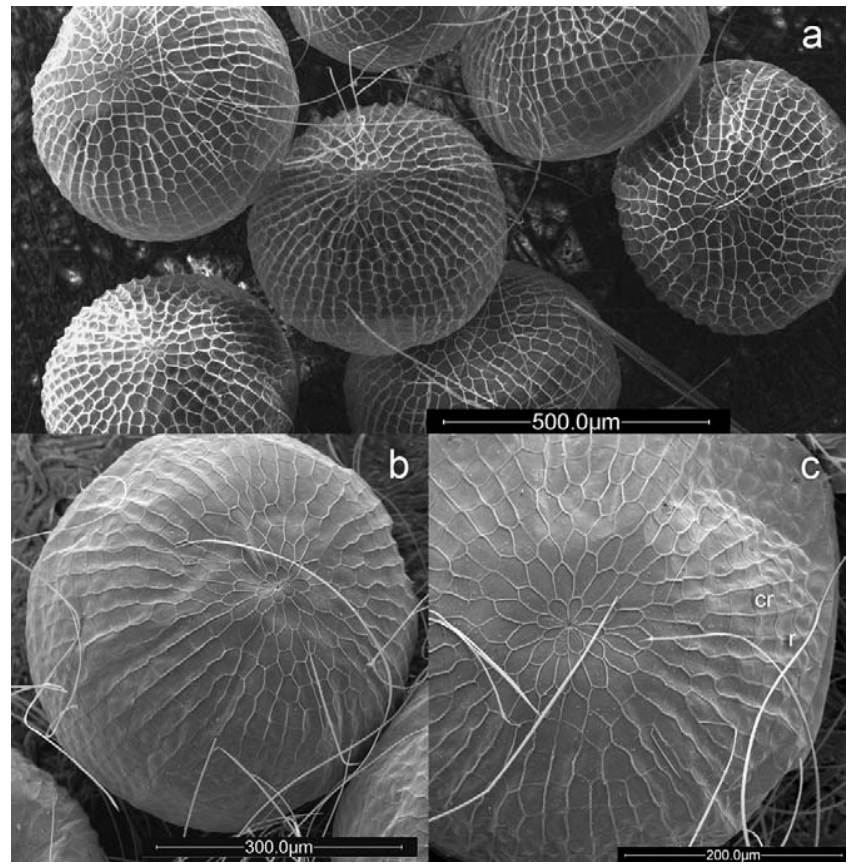

Fig. 3. (a) Eggshell surface topography of S. albula. (b) Eggshell surface topography of S. eridania and micropylar rosette. (c) Eggshell surface topography of S. cosmioides and hair silk on the egg surface. R, ribs; cr, crossribs; mi, micropyle. 


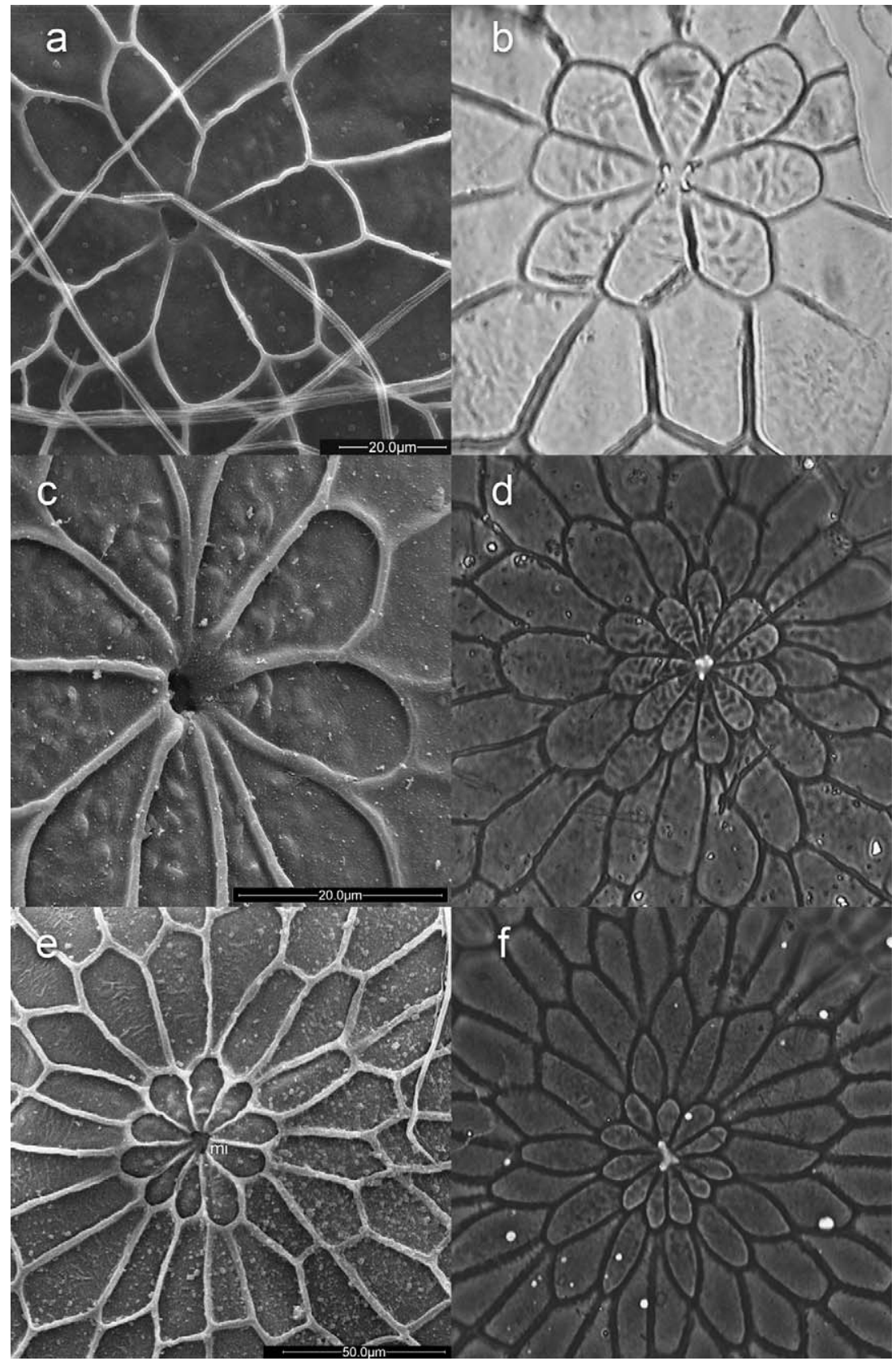

Fig. 4. Micropylar rosette of (a, b) S. albula, (c, d) S. eridania, and (e, f) S. cosmioides.

Spodoptera species lay egg masses, usually in layers, covered by abundant silk, normally spherical in shape and flattened at the base. Radial and cross ribs are conspicuous, and primary cells are not fused.

The egg masses of S. albula are pale green with gray hues and laid in one, two, or eventually three layers. They are usually spherical in shape and flattened at the base. In this study, the mean diameter of S. albula eggs was $505.4 \mu \mathrm{m}(475-540)$ and the mean height was $411.1 \mu \mathrm{m}$ (357-477). The mean numbers of ribs and micropyles were $52.3(46-57)$ and $3.5(3-4)$, respec-
Table 2. Measurements (micrometers) of surface structures of the eggshell of three Spodoptera species; mean (range) of $30 \mathrm{ob}-$ servations

\begin{tabular}{lccc}
\hline \hline Surface structure & S. albula & S. eridania & S. cosmioides \\
\hline Egg ht & $411.1(357-477)$ & $370.2(292-420)$ & $525.8(476-573)$ \\
Egg diam & $505.4(475-540)$ & $480.3(430-521)$ & $463.3(396-517)$ \\
No. primary cells & $9.1(6-11)$ & $10.6(8-14)$ & $10.2(8-12)$ \\
No. secondary cells & $15.7(12-19)$ & $20.3(17-26)$ & $21.2(17-26)$ \\
No. micropyles & $3.5(3-4)$ & $3.9(2-5)$ & $3.4(3-7)$ \\
No. ribs & $52.3(46-57)$ & $49.9(46-54)$ & $48.3(46-54)$ \\
Rosette diam & $66.2(49.7-99.1)$ & $55.33(36.3-78.7)$ & $41.81(29.7-53.0)$ \\
\hline
\end{tabular}




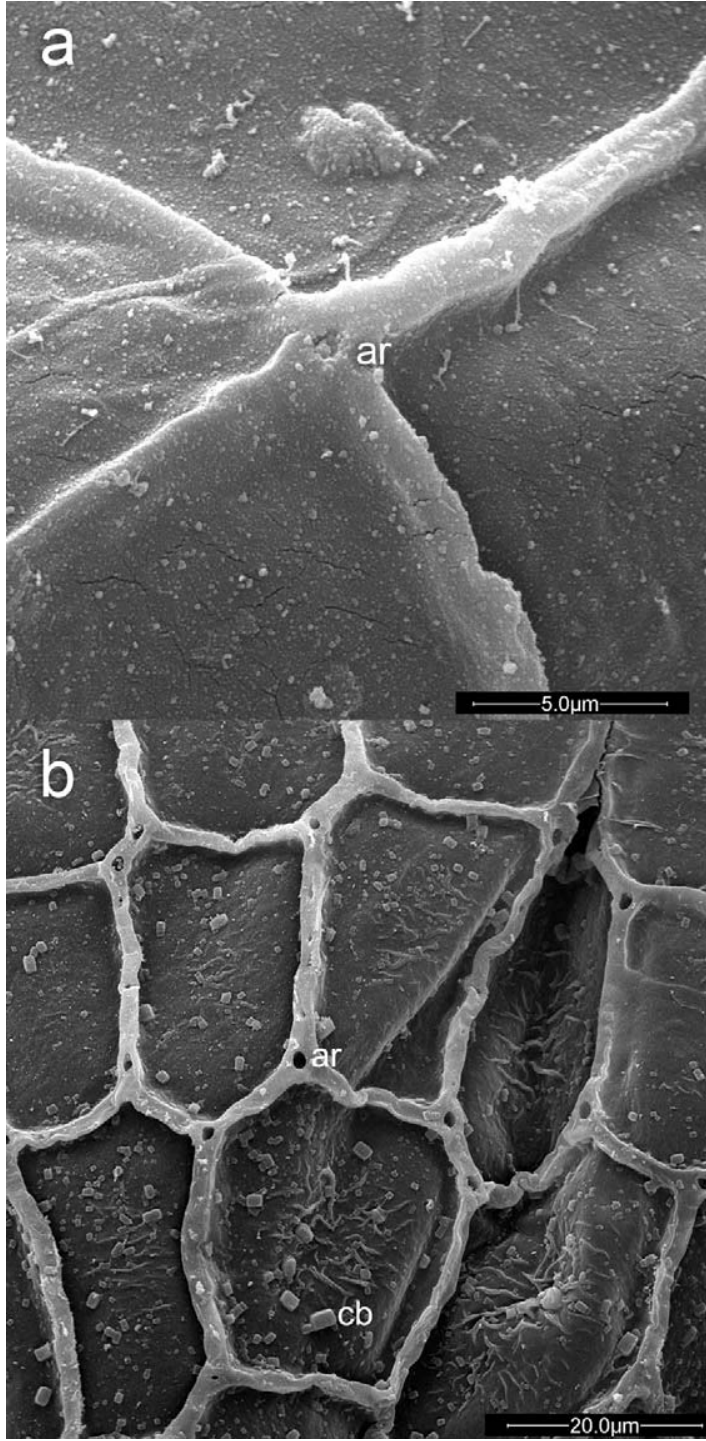

Fig. 5. Lateral surface topography of (a) S. eridania and (b) S. cosmioides. r, ribs; cr, crossribs; ar, aeropyles; cb, cuboid elements.

tively, and the micropyle was surrounded by a rosette composed of $9.1(6-11)$ primary cells (Figs. 3a and $4 \mathrm{a}$ and $b$; Table 2). The distal extremes of the rosette petals were angular in shape (Fig. $4 \mathrm{a}$ and b).

The egg masses of S. eridania are pale green, somewhat bright, and laid in one, two, or eventually three layers. They are spherical in shape and flattened at the base. In our study, the mean diameter of S. eridania eggs was $480.3 \mu \mathrm{m}(430-521)$ and the mean height was $370.2 \mu \mathrm{m}(292-420)$. The mean number of micropyles was $3.9(2-5)$, and they were surrounded by a rosette composed of $10.6(8-14)$ primary cells (Fig. $4 \mathrm{c}$ and $\mathrm{d}$; Table 2 ). The distal extremes of the rosette petals were round in shape (Fig. 4c and d). In this species, the mean numbers of ribs was $49.9(46-54)$,
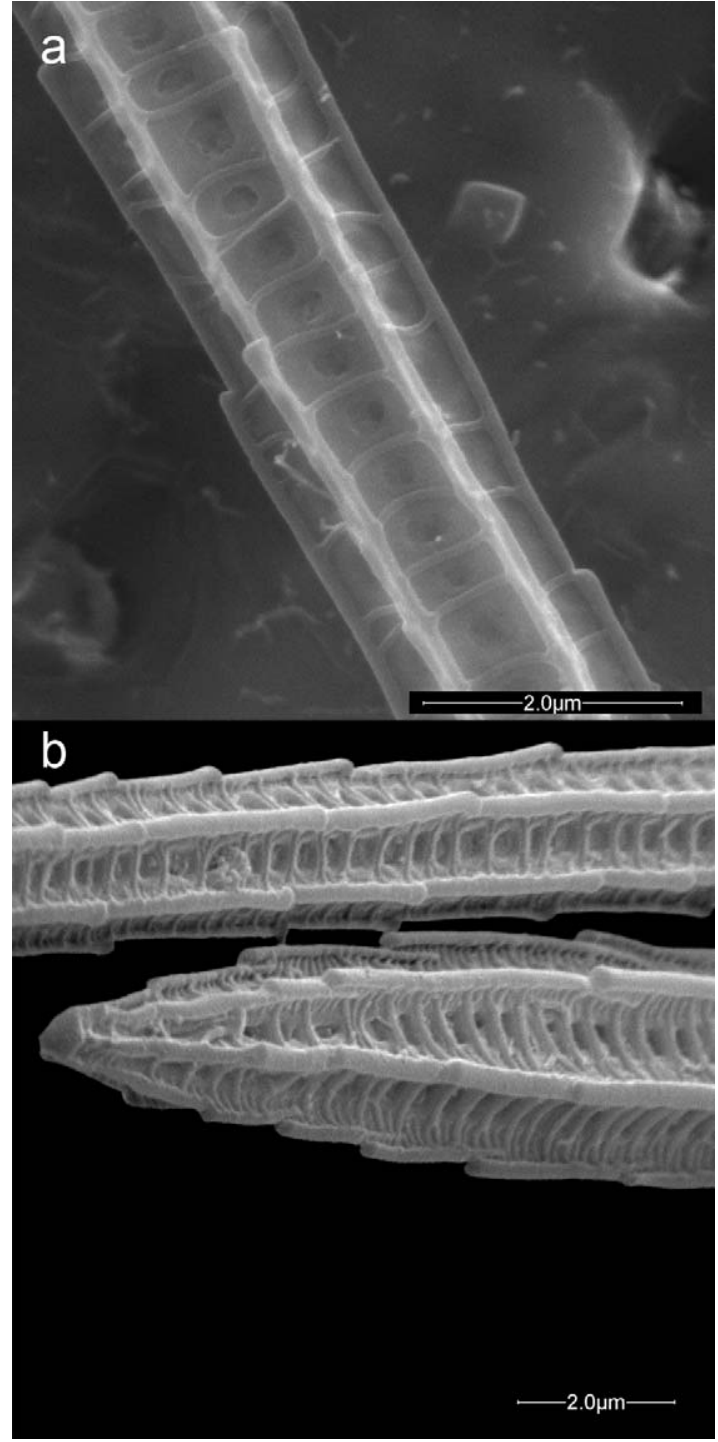

Fig. 6. (a) Silk (modified scales) of S. albula. (b) Tip of the silk of S. eridania, used to cover the egg mass.

within the range of S. albula and S. cosmioides (Table 2).

The egg masses of $S$. cosmioides present variable colors, ranging from green, gray, and brown to dull pink brownish, and they are laid in two or three layers. They are spherical in shape and flattened at the base. In the current study, the mean diameter of S. cosmioides eggs was $463 \mu \mathrm{m}$ (396-517) and the mean height was $525.8 \mu \mathrm{m}$ (476-573). The mean numbers of ribs and micropyles were $48.3(46-54)$ and $3.4(3-7)$, respectively, and the micropyle was surrounded by a rosette composed of 10.2 (8-12) primary cells (Fig. 4e and $\mathrm{f}$; Table 2). The distal extremes of the rosette petals were round in shape (Fig. 4e and f). Aeropyles are present on the conjunction points of the conspicuous ribs and cross-ribs (Fig. 5a and b). Masses of eggs 
Table 3. Sample list, location, host plant, collection dates, and haplotypes

\begin{tabular}{|c|c|c|c|c|}
\hline Species & Location & Host & Collection data & Haplotypes \\
\hline S. albula & Jaboticabal, SP & Peanuts & 2008 & 1 \\
\hline \multirow[t]{2}{*}{ S. cosmioides } & Pelotas, RS & Laboratory & NA & 1 \\
\hline & & Castor Oil & Feb. 2009 & $1 \& 2$ \\
\hline \multirow[t]{2}{*}{ S. eridania } & Santa Helena, GO & Cotton & Mar. 2010 & $1,2, \& 3$ \\
\hline & & Laboratory & NA & 4 \\
\hline C. includens & Rondonópolis, MT & Soybean & Dec. 2008 & $1,2,3, \& 4$ \\
\hline \multirow{2}{*}{ R. $n u$} & Vacaria, RS & Soybean & NA & $1,2,4, \& 6$ \\
\hline & Monte Redondo, Argentina & Soybean & Feb. 2012 & $1,3, \& 5$ \\
\hline
\end{tabular}

of Spodoptera species are covered by modified scales that are morphologically similar among species (Fig. $6 a$ and $b)$.

Partial sequencing of the mitochondrial (mt) COI amplicon from legs and eggs revealed an average size of $658 \mathrm{bp}$ for S. albula, S. eridania, S. cosmioides, C. includens, and R. nu. The mtDNA sequencing for the studied Spodoptera species corresponded to positions 1 or 2 and 658 of the sequence encoding the COI gene, partial cds in S. frugiperda (GenBank GU090723), as well as in C. includens (GenBank GU090374.1), and in A. gemmatalis (GenBank JN401299). We observed nonvariable sites in $S$. albula, one variable site in $S$. cosmioides, two variable sites in S. eridania and $C$. includens, and three variable nucleotide sites in $R . n u$ (Table 3). The recognition site for the restriction enzyme Bpm I (CTGGAGnnnnnnnnnnnnnn nn') was absent in $C$. includens and S. eridania, and the unrestricted amplification product remained with 710 bp. Amplified COI products were digested with restricted endonuclease and resulted in a single visible band, with different molecular weights (MW), for $S$. albula (600 bp), S. cosmioides (550 bp), and R. nu (700 bp), but for S. eridania and C. includens, the restriction enzyme Bpm I did not digest the final product of amplification (Fig. 7; Table 4). Restrict digestion PCR from S. albula, S. eridania, and C. includens products with MboI resulted in three visible bands, with different MW, for C. includens and R. nu [280 bp, $120 \mathrm{bp}$ (possibly, an overlap of bands of similar MW), and a faint band close to $50 \mathrm{bp}$ ], and for S. cosmioides ( $290 \mathrm{bp}, 120 \mathrm{bp}$, and faint band close to $100 \mathrm{bp}$ ) (Fig. 8). Restrict digestion PCR from S. eridania product with $\mathrm{MboI}$ resulted in three visible bands of $400 \mathrm{bp}$, a band close to $120 \mathrm{bp}$, and a faint band close to 50 bp (Fig. 8; Table 5). PCR-RFLP patterns (Tables 4 and 5) for Bmp I and MboI in S. albula, S. cosmioides, S. eridania, C. includens, and R. nu were-AA, BB, $\mathrm{CA}, \mathrm{CB}$, and $\mathrm{CB}$, respectively. The presence of haplotypes in all the noctuid species had no influence on RFLP patterns. Agarose gel electrophoresis was not able to distinguish between C. includens and R. $n u$.

\section{Discussion}

Morphological differences between the Plusiinae (Noctuidae) species studied here and A. gemmatalis (Erebidae: Eulepidotinae) are easily distinguished by the rosette petals and the conspicuous ribs present in A. gemmatalis eggs (Cônsoli et al. 1999). Another feature that distinguishes A. gemmatalis from both Plusiinae species is the short radial threads in high relief that are present inside all rosette petals of $C$. includens and R. $n u$ but are absent in A. gemmatalis (Fig. 1c and d). However, morphological differences between C. includens and $R$. nu eggs are almost indistinguishable. Angulo et al. (2006) described a dichotomic key based

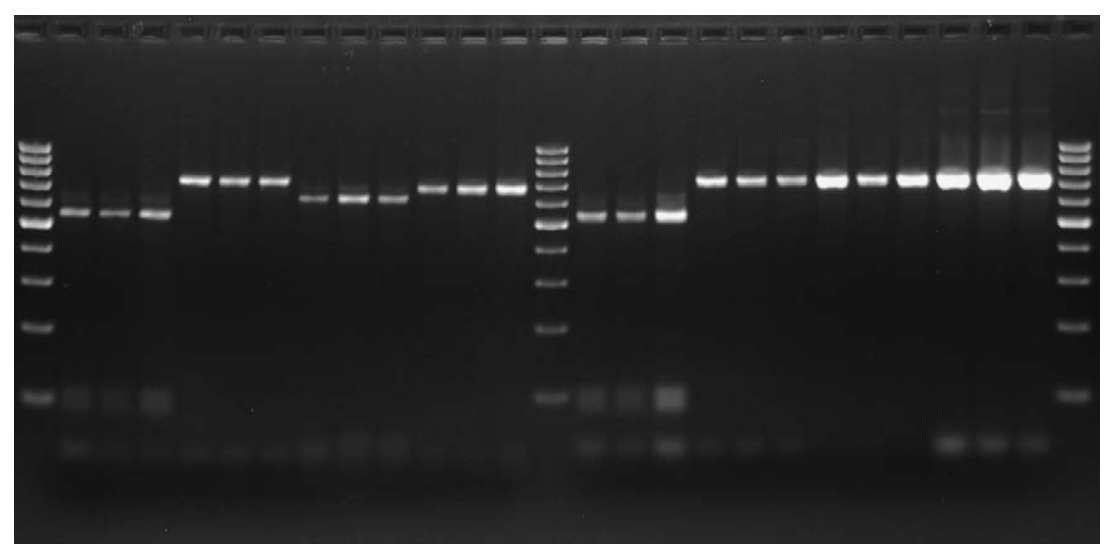

Fig. 7. PCR-RFLP agarose gel (2\%) for COI amplification products using Bpm I endonuclease. Lane 1: 100 bp MW; lanes 2-4: digestion product of S. cosmioides; lanes 5-7: digestion product of S. eridania; lanes 8-10: digestion product of S. albula; lanes 11-13: digestion product of R. nu; lane 14: $100 \mathrm{bp} \mathrm{MW;} \mathrm{lanes} \mathrm{15-17:} \mathrm{digestion} \mathrm{product} \mathrm{of} \mathrm{S.} \mathrm{cosmioides;}$ lanes 18-20: digestion product of S. eridania; lanes 21-26: digestion product of C. includens; lane 27: $100 \mathrm{bp}$ MW. 
Table 4. Restriction sites and fragment size after restriction digestion of COI amplification products from Noctuidae species using the restriction enzyme Bpm I

\begin{tabular}{lccc}
\hline \multicolumn{1}{c}{ Species } & Restriction site & Fragment size $(\mathrm{bp})$ & Pattern \\
\hline S. albula & 643,583 & $15,60,583$ & $\mathrm{~A}$ \\
S. cosmioides & 583,67 & $67,75,516$ & $\mathrm{~B}$ \\
S. eridania & No digestion & 658 & $\mathrm{C}$ \\
C. includens & No digestion & 658 & $\mathrm{C}$ \\
R. $n u$ & 643 & 15,643 & $\mathrm{C}$ \\
\hline
\end{tabular}

on egg microstructure and reported that $R$. nu presents 25-46 lateral ribs, whereas C. includens has 31-33, according to Peterson (1964). Furthermore, the eggs of $C$. includens are hemispherical, with the basal part, at the opposite side of the micropylar region, flattened. Radial and transversal ribs are more conspicuous in $C$. includens than in R. nu.

The main characteristic that could be used to distinguish the eggs of Spodoptera from A. gemmatalis and Plusiinae is the "net" appearance of the surface with no conspicuous ribs in Spodoptera (Fig. 3a-c), together with the presence of modified scales (silk) covering the egg masses.

S. albula presented a lower number of primary cells than that observed in S. eridania and S. cosmioides, although the primary cells are bigger in S. albula (Fig. 4; Table 2). Observations with light microscopy suggest that all traits overlap (Table 2). The eggs of Spodoptera species are covered by modified scales (silk) as usually mentioned (Beserra et al. 2002, Valverde 2007). Variation in egg color is expected depending on the diet and the age of the eggs (Cônsoli et al. 1999, Valverde 2007).

The current study shows that S. albula presented a higher number of ribs $(46-57)$ than that observed by Peterson (1964) (47-50), who referred to the species as $P$. sunia. Regional morphological variability in number of ribs has been found in other noctuid species, such as Peridroma saucia, which in the United States has 43-44 ribs (Peterson 1964) and in Chile, 62-70 ribs (Angulo et al. 2006).
Table 5. Restriction sites and fragment size after restriction digestion of COI amplification products from Noctuidae species using MboI

\begin{tabular}{lccc}
\hline \multicolumn{1}{c}{ Species } & Restriction site & $\begin{array}{c}\text { Fragment size } \\
(\mathrm{bp})\end{array}$ & Pattern \\
\hline S. albula & $87,104,488,587$, & $17,18,26,27,87$, & $\mathrm{A}$ \\
S. cosmioides & $87,104,375,488$, & $17,27,44,87,99$, & $\mathrm{B}$ \\
S. eridania & $58,104,614$ & 113,271 & \\
& $67,17,58,587$, & $17,26,45,87,99$, & $\mathrm{A}$ \\
C. includens & $87,104,375,488$, & $17,18,26,27,87$, & $\mathrm{B}$ \\
& $587,614,632$ & $99,113,271$ & \\
R. nu & $87,104,375,488$, & $17,26,45,87,99$, & $\mathrm{B}$ \\
& 587,632 & 113,271 & \\
\hline
\end{tabular}

Insect species identification or differentiation based on morphological characteristics of undifferentiated phases, such as eggs or small larvae, can be inaccurate. Therefore, additional molecular characterization, based on the nucleotide sequence of the first portion of the mitochondrial COI gene, was used in this study. This region of the mtDNA genome has been widely used as DNA barcoding for species identification (Jinbo et al. 2011). Also, PCR-RFLP analyses of these gene fragments can be useful to determine differences among species. Double digestion with Bpm I and MboI may be confusing, considering the multiple bands generated after the process.

Although band separation is better in polyacrylamide gel, in this study, agarose gel was used because of the lower cost and nontoxic reagents. RFLP patterns produced by Bpm I endonuclease was useful to discriminate species within Spodoptera (S. cosmioides, S. eridania, and S. albula), but no differences between R. $n u$ and C. includens were found. Bmp I did not digest the amplicons from S. eridania and C. includens, which were discriminated by RFLP patterns produced by MboI enzyme. PCR-RFLP methodology showed diagnostic utility to distinguish the most important Lepidoptera species associated with soybean production. Additional studies, with a more extensive sampling,

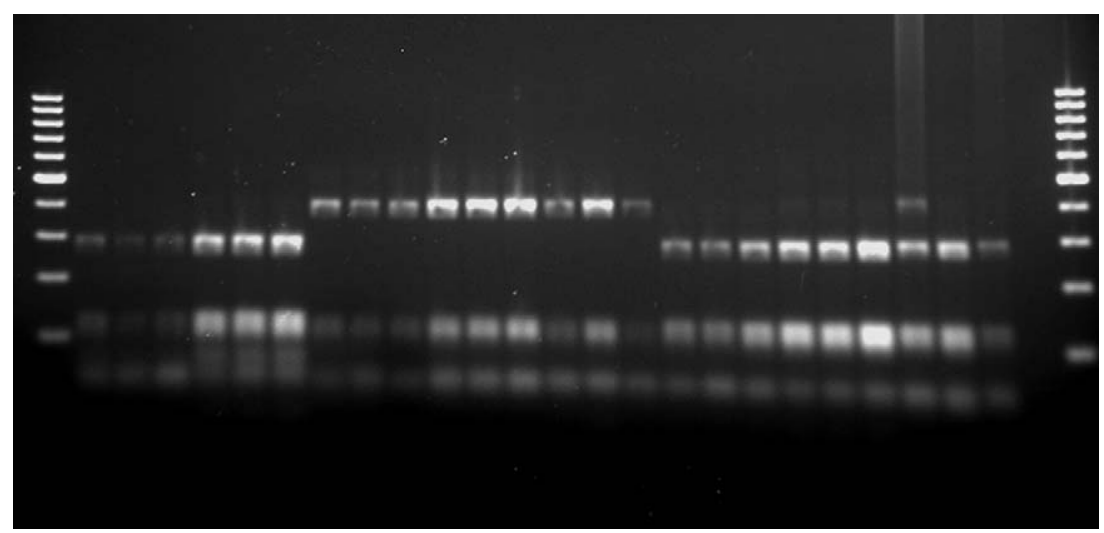

Fig. 8. PCR-RFLP agarose gel (2\%) for COI amplification products using MboI endonuclease. Lane 1: 100 bp MW; lanes 2-7: digestion product of S. cosmioides (adults and eggs); lanes 8-13: digestion product of S. eridania (adults and eggs); lanes 14-16: digestion product of S. albula; lanes 17-22: digestion product of C. includens (adults and eggs); lanes 23-25: digestion product of $R$. nu; lane 26: digestion without DNA template; lane 27: $100 \mathrm{bp}$ MW 
are necessary, as different haplotypes may occur in related species belonging to the same genus or family, such as S. frugiperda (Nagoshi et al. 2007) and $H$. virescens (Albernaz et al. 2012).

\section{Acknowledgments}

We thank Eliamar Pedrinho for the contribution with the sequencing work and Osvaldo Capello, Laboratory of Electron Microscopy and Microanalysis, Londrina State University, PR, Brazil. This research was supported by Embrapa Soja and Conselho Nacional de Desenvolvimento Científico e Tecnológico (CNPq-Process no. 475250/2011-7). This article was approved by the editorial board of Embrapa as manuscript $07 / 2013$.

\section{References Cited}

Albernaz, K. C., K. L. Silva-Brandão, P. Fresia, F. L. Cônsoli, and C. Omoto. 2012. Genetic variability and demographic history of Heliothis virescens (Lepidoptera: Noctuidae) populations from Brazil inferred by mtDNA sequences. Bull. Entomol. Res. 102: 333-343.

Angulo, A. O., T. S. Olivares, and G. T. Weigert. 2006. Estados Inmaduros de Lepidópteros Nóctuidos de Importancia Económica Agrícola y Forestal en Chile (Lepidoptera: Noctuidae). Universidad de Concepción, Concepción.

Barbut, J. 2008. Révision du genre Rachiplusia Hampson, 1913 (Lepidoptera, Noctuidae, Plusiinae). Bull. Soc. Entomol. France 113: 445-452.

Beserra, E. B., C. T. Dias, and J.R.P. Parra. 2002. Distribution and natural parasitism of Spodoptera frugiperda (Lepidoptera: Noctuidae) eggs at different phenological stages of corn. Fla. Entomol. 85: 588-593.

Braga, D.P.V., W. S. Oliveira, S. Martinelli, D. R. SosaGómez, and M. F. Oliveira. 2011. Estudo de caso da soja MON 87701 x MON 89788, pp. 347-390. In A. Borem and G. Almeida (eds.), Plantas Geneticamente Modificadas. Desafios e Oportunidades Para Regiões Tropicais, vol 1. Universidade Federal de Viçosa, Viçosa.

Cônsoli, F. L., E. W. Kitajima, and J.R.P. Parra. 1999. Ultrastructure of the natural and factitious host eggs of Trichogramma galloi Zucchi and Trichogramma pretiosum Riley (Hymenoptera: Trichogrammatidae). Int. J. Insect Morphol. Embryol. 28: 211-231.

Eichlin, T. D., and H. B. Cunningham. 1978. The Plusiinae (Lepidoptera: Noctuidae) of American North of Mexico, Emphasizing Genitalic and Larval Morphology. USDA Technical Bulletin, 1567. United States Department of Agriculture, Washington, DC.
Folmer, O., M. Black, W. Hoeh, R. Lutz, and R. Vrijenhoek. 1994. DNA primers for amplification of mitochondrial cytochrome c oxidase subunit I from diverse metazoan invertebrates. Mol. Mar. Biol. Biotechnol. 3: 294-299.

Hoy, M. 1994. Insect molecular genetics: an introduction to principles and applications. Academic, San Diego, CA.

Jinbo, U., T. Kato, and M. Ito. 2011. Current progress in DNA barcoding and future implications for entomology. Entomol. Sci. 14: 107-124.

Lewter, J. A., and A. L. Szalanski. 2007. Molecular identification of the fall armyworm, Spodoptera frugiperda (J. E. Smith) (Lepidoptera: Noctuidae) using PCR-RFLP. J. Agric. Urban Entomol. 24: 51-57.

Olivares, T. S., S. A. Torres, and L. A. Zuñiga. 2005. Morfología de huevos de siete especies de nóctuidos de Chile (Lepidoptera: Noctuidae) y clave actualizada para su identificación. Rev. Biol. Trop. 53: 153-163.

Nagoshi, R. N., P. Silvie, R. L. Meagher, J. Lopez, and V. Machado. 2007. Identification and comparison of fall armyworm (Lepidoptera: Noctuidae) host strains in Brazil, Texas, and Florida. Ann. Entomol. Soc. Am. 100: 394-402.

Peterson, A. 1961. Some types of eggs deposited by moths, Heterocera-Lepidoptera. Fla. Entomol. 44: 107-114.

Peterson, A. 1964. Egg types among moths of the Noctuidae (Lepidoptera). Fla. Entomol. 47: 71-91.

Pogue, M. G. 2002. A world revision of the genus Spodoptera Guenée (Lepidoptera: Noctuidae). Mem. Am. Entomol. Soc. 43: 1-202.

Rogers, S. O., and A. J. Bendich. 1988. Extraction of DNA from plant tissues, pp. 1-10. In S. B. Gelvin, R. A. Schilperpoort, and D.P.S. Verma (eds.), Plant Molecular Biology Manual. Kluwer Academic, Dordrecht, The Netherlands.

Sosa-Gómez, D. R., B. S. Corrêa-Ferreira, C. B. HoffmannCampo, I. C. Corso, L. J. Oliveira, F. Moscardi, A. R. Panizzi, A. F. Bueno, and E. Hirose. 2010. Manual de identificação de insetos e outros invertebrados da cultura da soja, 2nd ed. Embrapa Soja, Londrina. Documentos.

Simon, C., F. Frati, A. Beckenbach, B. Crespi, H. Liu, and P. Flook. 1994. Evolution, weighting, and phylogenetic utility of mitochondrial gene sequences and a compilation of conserved polymerase chain reaction primers. Ann. Entomol. Soc. Am. 87: 651-701.

Thompson, J. D., D. G. Higgins, and T. J. Gibson. 1994. CLUSTAL W: improving the sensitivity of progressive multiple sequence alignment through sequence weighting, position-specific gap penalties and weight matrix choice. Nucleic Acid Res. 22: 4673-4680.

Valverde, L. 2007. Microestructura del huevo de Spodoptera eridania (Stoll, 1782) (Lepidoptera: Noctuidae). Acta Zool. Lilloana 51: 53-56.

Received 8 April 2013; accepted 22 July 2013. 